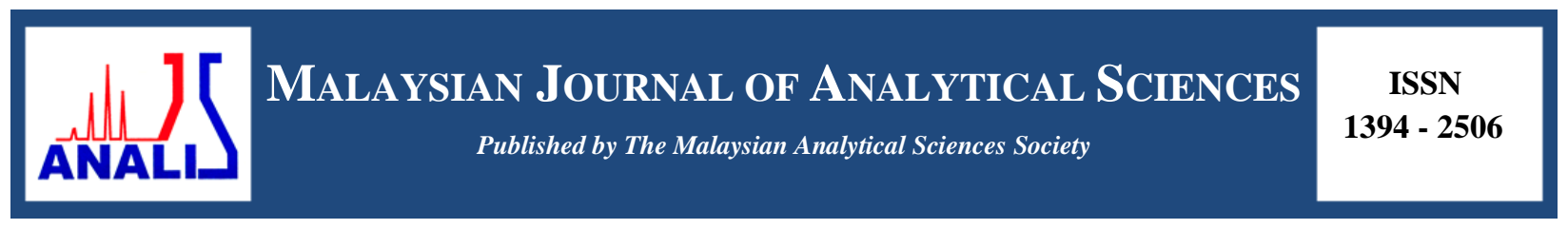

\title{
IMMOBILIZATION OF HIGHLY EFFECTIVE PALLADIUM CATALYST ONTO POLY(4-VINYLPYRIDINE): SYNTHESIS AND CHARACTERIZATION
}

\author{
(Pemegunan Mangkin Paladium yang Efektif ke atas Poli(4-vinilpiridina): \\ Sintesis dan Pencirian) \\ Siti Kamilah Che Soh ${ }^{1}$, Intan Shafinass Kassim ${ }^{1}$, Siti Aminah Jusoh ${ }^{1}$, Mustaffa Samsuddin ${ }^{2,3}$ \\ ${ }^{I}$ Analytical \& Environmental Chemistry Program, School of Marine and Environmental Sciences, \\ Universiti Malaysia Terengganu, 21030 Kuala Terengganu, Terengganu, Malaysia \\ ${ }^{2}$ Department of Chemistry, Faculty of Science \\ ${ }^{3}$ Ibnu Sina Institute for Fundamental Science Studies \\ Universiti Teknologi Malaysia, 81310 Johor Bahru, Johor, Malaysia \\ *Corresponding author: sitikamilah@umt.edu.my
}

Received: 24 February 2015; Accepted: 27 October 2015

\begin{abstract}
A commonly known weakness of homogeneous catalysts is the difficulty to recover the active catalyst from the product. Due to the disadvantage, the designing of supported catalyst has been approached to overcome the separation difficulty of the palladium-based homogeneous catalyst. New polymer supported $\mathrm{N}_{2} \mathrm{O}_{2}$ metal complex was successfully immobilized by mixing of poly(4-vinylpyridine) with palladium(II) complex in the presence of ethyl acetate as solvent. Then, the reaction was stirred for 72 hours at room temperature to form corresponding $\mathrm{P}_{4} \mathrm{VP}-\mathrm{Pd}$ catalyst. The properties of immobilized catalyst were characterized by various techniques such as fourier transform infrared (FTIR), thermogravimetric (TGA), X-ray diffraction (XRD), scanning electron microscopy/energy dispersive X-ray (SEM/EDX) and inductively coupled plasma-optical emission (ICP-OES) spectroscopy.
\end{abstract}

Keywords: immobilized catalyst, palladium(II) complex, poly(4-vinylpyridine)

\begin{abstract}
Abstrak
Satu kelemahan penggunaan mangkin homogen adalah umum diketahui bahawa kesukaran untuk memperoleh kembali mangkin yang aktif daripada hasil produk. Oleh kerana kelemahan ini, reka bentuk mangkin berpenyokong telah diperkenalkan untuk mengatasi kesukaran pemisahan mangkin homogen berasaskan logam paladium. Kompleks logam $\mathrm{N}_{2} \mathrm{O}_{2}$ berpenyokong polimer baru telah berjaya dipegunkan dengan mencampurkan poli(4-vinilpiridina) dengan kompleks paladium(II) dengan kehadiran etil asetat sebagai pelarut. Kemudian, campuran tindak balas dikacau selama 72 jam pada suhu bilik untuk menghasilkan mangkin $\mathrm{P}_{4} \mathrm{VP}-\mathrm{Pd}$. Sifat - sifat mangkin yang berjaya dipegunkan telah dicirikan dengan pelbagai teknik spektroskopi antaranya infra merah transformasi fourier (FTIR), analisis termogravimetrik (TGA), pembelauan sinar-X (XRD), mikroskopi elektron imbasan/ sinar-X tenaga tersebar (SEM/EDX) dan spektroskopi pancaran optik-aruhan (ICP-OES).
\end{abstract}

Kata kunci: mangkin terpegun, kompleks paladium(II), poli(4-vinilpiridina) 


\section{Introduction}

Historically, the homogeneous catalysts have been developed to be used in industry earlier than heterogeneous catalyst. Homogeneous catalyst offered a several number of advantages to the researchers. It was found the homogeneous catalyst having transition metal complexes exhibited high selectivity and activity [1]. Despite of its advantages, the homogeneous catalyst is not commonly used as heterogeneous catalyst due to its difficulties to recover. These was proven when Dunnewijk et al. [2] reported that homogeneous catalyst is not widely used in chemical industry because the catalyst is difficult to recover and the catalysts also suffer from corrosion problems and product contamination [2]. Moreover, the homogeneous metal catalyst such as palladium is expansive to afford, toxic and suffered from prohibited drawbacks deactivation of poor conversion [3] Therefore, due to these reason there is a need to use the most applicable catalyst which is heterogeneous catalyst where the metal is heterogenized on a polymer support [4]. Other than that, heterogeneous catalyst offered easy recovery of catalyst from the reaction mixture by simple filtration and can be reused for several times [5].

One of the reasons palladium is commonly used in research because palladium is one of the most versatile of the transition metals and can formed coordination with electron donor atoms such as nitrogen and oxygen [6]. Due to these reason, Evangelisti et al. [7] discovered that the development of heterogeneous Schiff base a phosphine-free palladium catalyst which is economic and its environmental points of view have been done [7]. Schiff base is a compound which consists of nitrogen analogue of an aldehyde or ketone in which carbonyl group $(\mathrm{C}=\mathrm{O})$ have been replaced with an imine or azomethine group. The Schiff base compounds or also known as azomethines are very easy to be prepared from relatively inexpensive material and these selective ligands are sensitive towards most of the metal ions $[8-10]$.

Polymers have been widely explored as immobilised material for supported catalyst [11]. In this research, poly(4vinylpyridine $\left(\mathrm{P}_{4} \mathrm{VP}\right)$ has emerged as an interesting approach for catalyst support to the Schiff base metal complex. $\mathrm{P}_{4} \mathrm{VP}$ has gained interest due to its stability towards high temperature resistance, hardness, impact strength, and its transparency can be precisely controlled through the metallocene structure.

In this present paper, the synthesis and characterization of the poly(4-vinylpyridine) supported palladium(II)-Schiff base complex which highly potential as heterogeneous catalyst for carbon-carbon bond formation were reported.

\section{Materials}

\section{Materials and Methods}

All of the reagents which included chemicals, materials and solvent are analytical grade and commercially purchased from standard suppliers (Aldrich and Fluka) were used without further purification. All reactions were carried out under an ambient atmosphere and no special precaution was taken to exclude air or moisture during synthesis work-up.

\section{Synthesis of N,N'-bis(3,5-di-tert-butylsalicylidene)-propane-1,3-diamine}

The $\mathrm{N}_{2} \mathrm{O}_{2}$-Schiff base ligand was synthesized according to the literature methods $[12,13]$. The spectroscopic characterizations of these ligands were in agreement with literature values.

\section{Synthesis of N,N'-bis(3,5-di-tert-butylsalicylidene)-propane-1,3-diaminepalladium(II) complex}

The Pd(II) complex (Scheme 1) was synthesized following standard method [14]. The complex was prepared by treating an equivalent molar amount of the corresponding ligand with $\mathrm{Pd}(\mathrm{OAc})_{2}$ in acetonitrile. The spectroscopic data $\left({ }^{1} \mathrm{H},{ }^{13} \mathrm{C}\right.$ NMR and FTIR) of this complex are in agreement with those reported recently by Soh et al. [15] .Yield: $88 \%$. Melting point: $375-376{ }^{\circ} \mathrm{C}$. CHN elemental analysis (\%): Experimental: C, 55.60; H, 6.53; N, 3.82. Calculated for $\mathrm{C}_{33} \mathrm{H}_{48} \mathrm{~N}_{2} \mathrm{O}_{2}$ Pd requires: $\mathrm{C}, 64.85 ; \mathrm{H}, 7.92 ; \mathrm{N}, 4.58$

\section{Synthesis of Poly(4-vinylpyridine) supported Pd(II) complex}

The poly(4-vinylpyridine) ( $0.8 \mathrm{~g})$ was loaded into round bottom flask containing complex $(0.8 \mathrm{~g})$ with ethyl acetate as a solvent. The solution was stirred for 72 hours at room temperature (Scheme 2). The resultant solid catalyst was filtered off and washed with ethyl acetate two times followed by acetone. The residue was dried in air for 24 hours. 


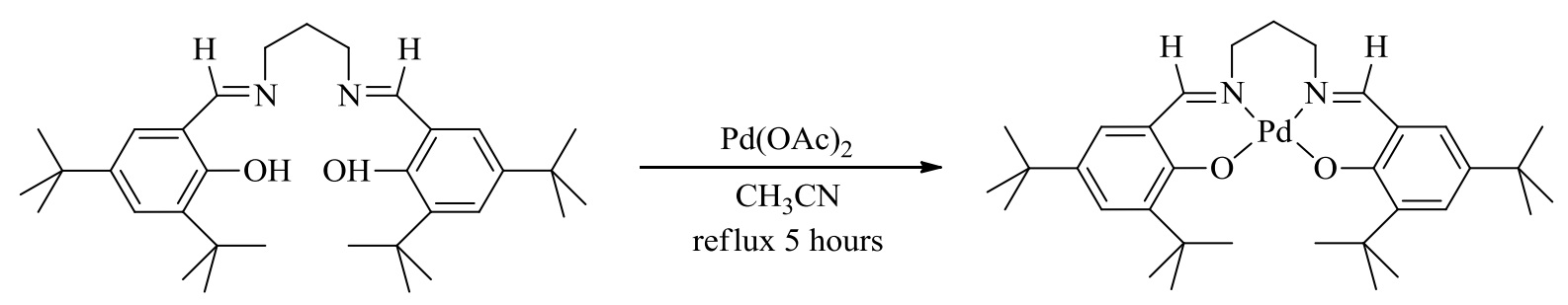

Scheme 1. Synthesis of N,N'-bis(3,5-di-tert-butylsalicylidene)-propane-1,3-diaminepalladium
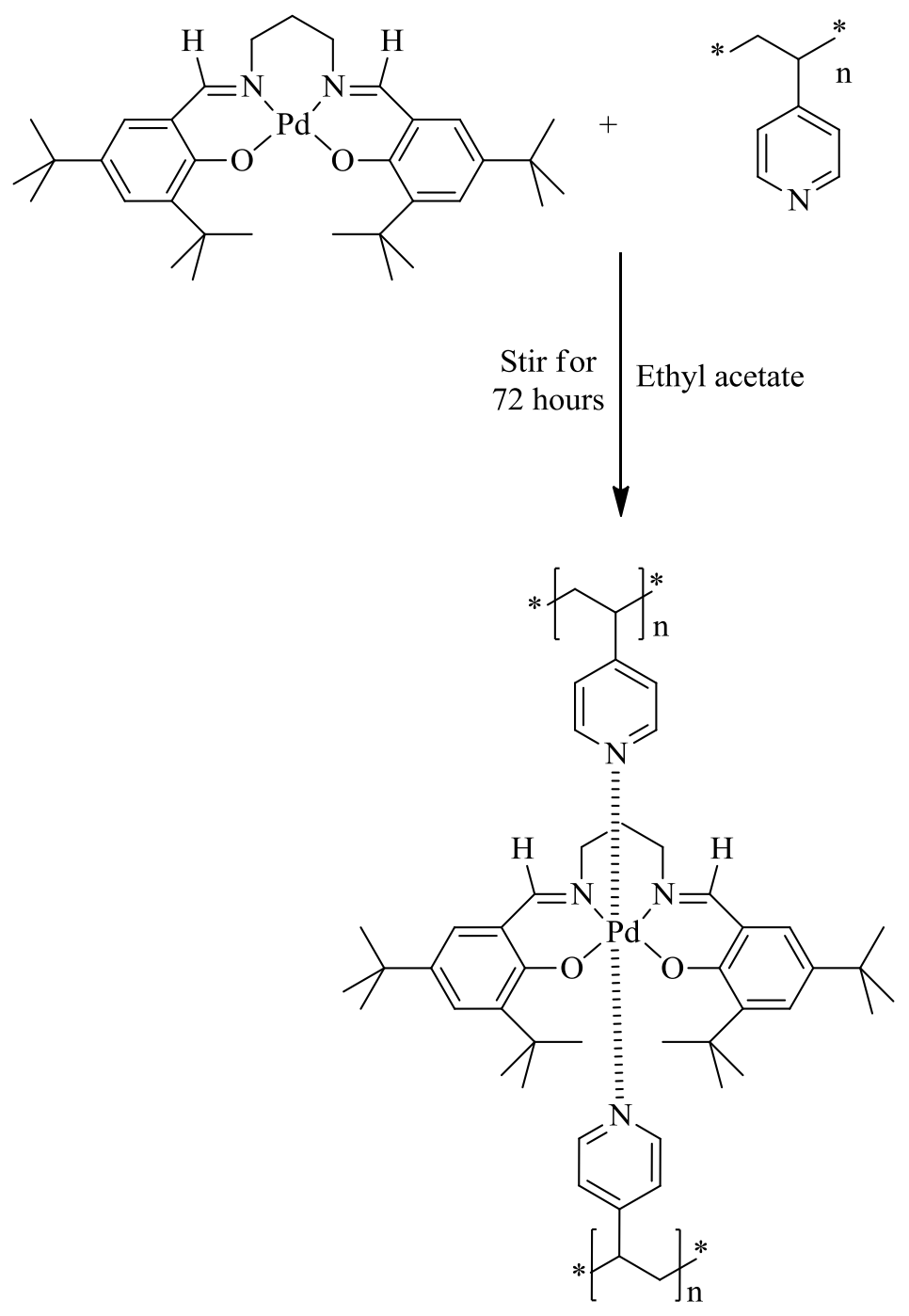

Scheme 2. Synthesis of poly(4-vinylpyridine) supported Pd(II) complex 


\section{Synthesis of $\mathrm{N}_{2} \mathrm{O}_{2}$ Schiff Base ligand and Palladium(II) complex}

The Schiff base ligand N,N'-bis(3,5-di-tert-butylsalicylidene)-propane-1,3-diamine was obtained yellow solid in high yield through condensation reaction between 3,5-di-tert-butyl-2-hydroxybenzaldehyde with 1,3diaminopropane. The resulting ligand was further treated with palladium(II) acetate in order to form metal complex. The synthesis of the Schiff base palladium(II) complex is shown in Scheme 1.

\section{Synthesis of Poly(4-vinylpyridine) supported Pd(II) complex}

The outline for synthesizing of $\mathrm{P}_{4}$ VP-Pd(II) complex was presented in Scheme 2. $\mathrm{The} \mathrm{N}_{2} \mathrm{O}_{2}$ palladium(II) complex was then immobilized onto poly(4-vinylpyridine) solid support in order to obtain heterogeneous catalyst of $\mathrm{P}_{4} \mathrm{VP}$ Pd(II) complex. The immobilized P4VP-Pd(II) complex was well characterized by FTIR, TGA, XRD, SEM-EDX and ICP-OES. The amount of metal present determined by ICP-OES suggested $0.361 \mathrm{mmol} / \mathrm{g}$ palladium loading onto supported palladium complex.

FTIR spectrum (Figure 1) showed the important bands of $\mathrm{P}_{4} \mathrm{VP}-\mathrm{Pd}(\mathrm{II})$ complex are located at $1610.73 \mathrm{~cm}^{-1}$, $3401.29 \mathrm{~cm}^{-1}$, and $1456.16 \mathrm{~cm}^{-1}$ due to stretching vibration of $v(\mathrm{C}=\mathrm{N}), \mathrm{v}(\mathrm{N}-\mathrm{H})$ and $v(\mathrm{C}=\mathrm{C})$. The thermal stability curves of $\mathrm{P}_{4} \mathrm{VP}$ and its supported $\mathrm{Pd}(\mathrm{II})$ complex are presented in Figure 2 were carried out at a heating rate of $10{ }^{\circ} \mathrm{C} \mathrm{min}^{-1}$ in nitrogen over a temperature range of 30-700 ${ }^{\circ} \mathrm{C}$. TGA data demonstrated that $\mathrm{P}_{4} \mathrm{VP}$ and $\mathrm{P}_{4} \mathrm{VP}-\mathrm{Pd}$ (II) complex degraded at considerably high temperature. $\mathrm{P}_{4} \mathrm{VP}-\mathrm{Pd}(\mathrm{II})$ complex was stable up to $330{ }^{\circ} \mathrm{C}$ and above this temperature it undergo decomposition process.

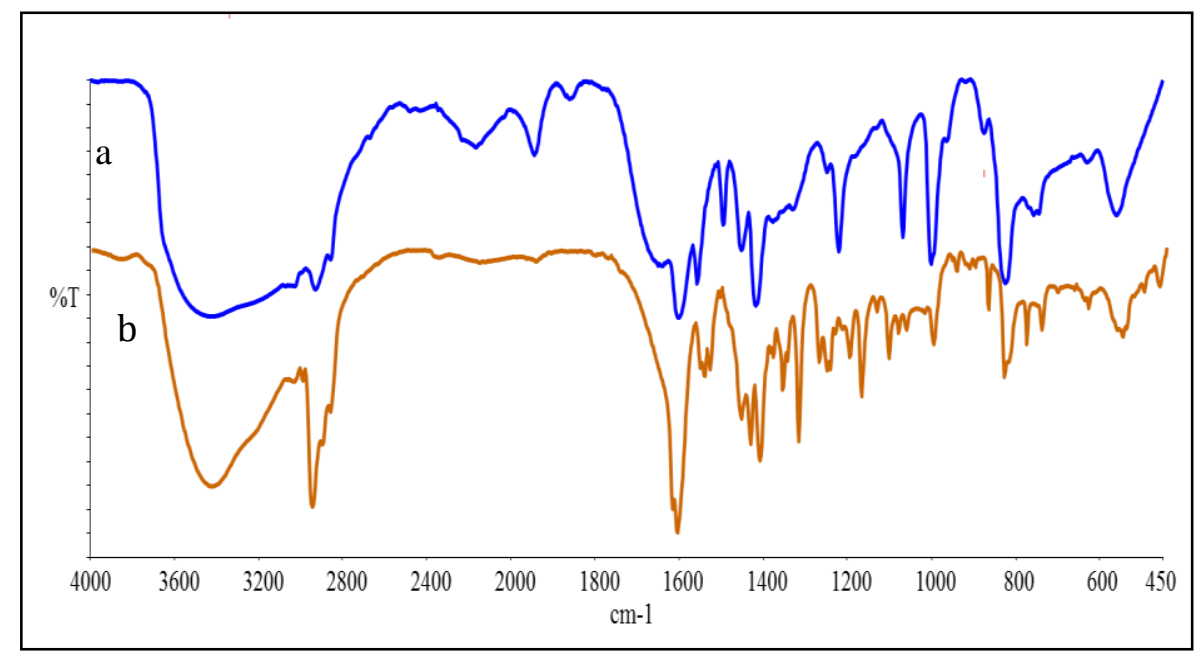

Figure 1. The FTIR spectrum for (a) $\mathrm{P}_{4} \mathrm{VP}$ and (b) $\mathrm{P}_{4} \mathrm{VP} \mathrm{Pd}$ (II) complex

The surface morphological features of each sample of $\mathrm{P}_{4} \mathrm{VP}$ and $\mathrm{P}_{4} \mathrm{VP}-\mathrm{Pd}(\mathrm{II})$ complex were observed using SEM (Figure 3) equipped with energy dispersive X-ray spectroscopy (EDX) (Figure 3). The morphology of $\mathrm{P}_{4} \mathrm{VP}$ shows as compact and lumps surface. Meanwhile, the morphology of $\mathrm{P}_{4} \mathrm{VP}-\mathrm{Pd}$ (II) complex has changed and small like particles are observable through the specimen. This could be due to the existence of palladium crystallite. The EDX data (Figure 4) clearly supported the presence of palladium metal on the surface of polymeric chain of poly(4vinylpyridine). 


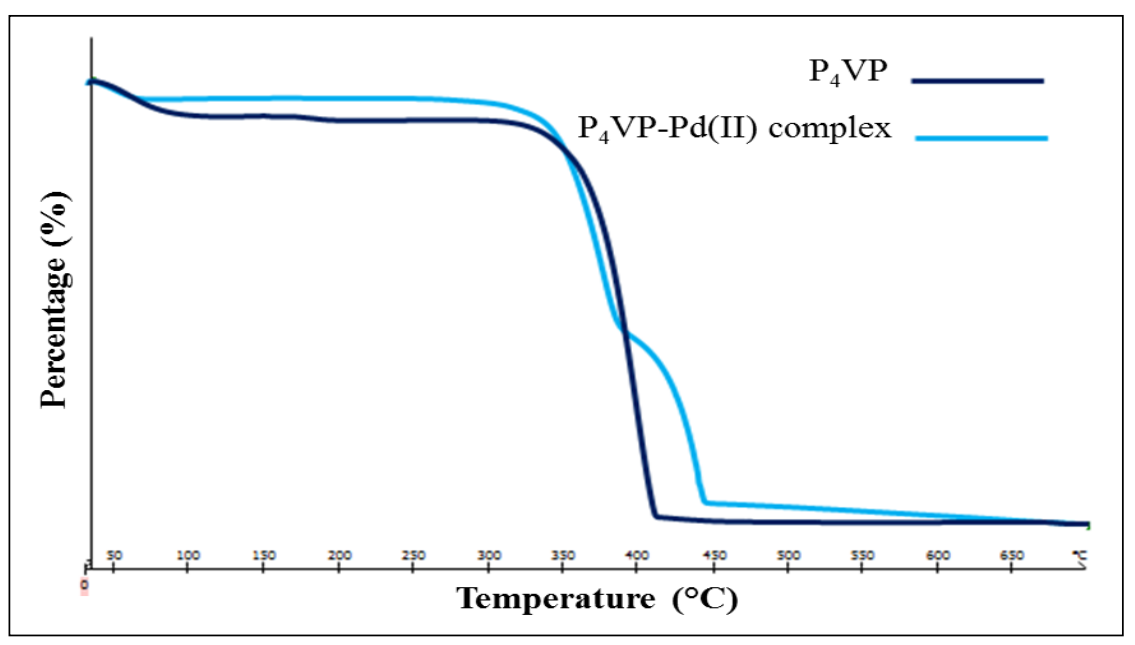

Figure 2. The TGA curves of the supported catalysts and free $\mathrm{P}_{4} \mathrm{VP}$
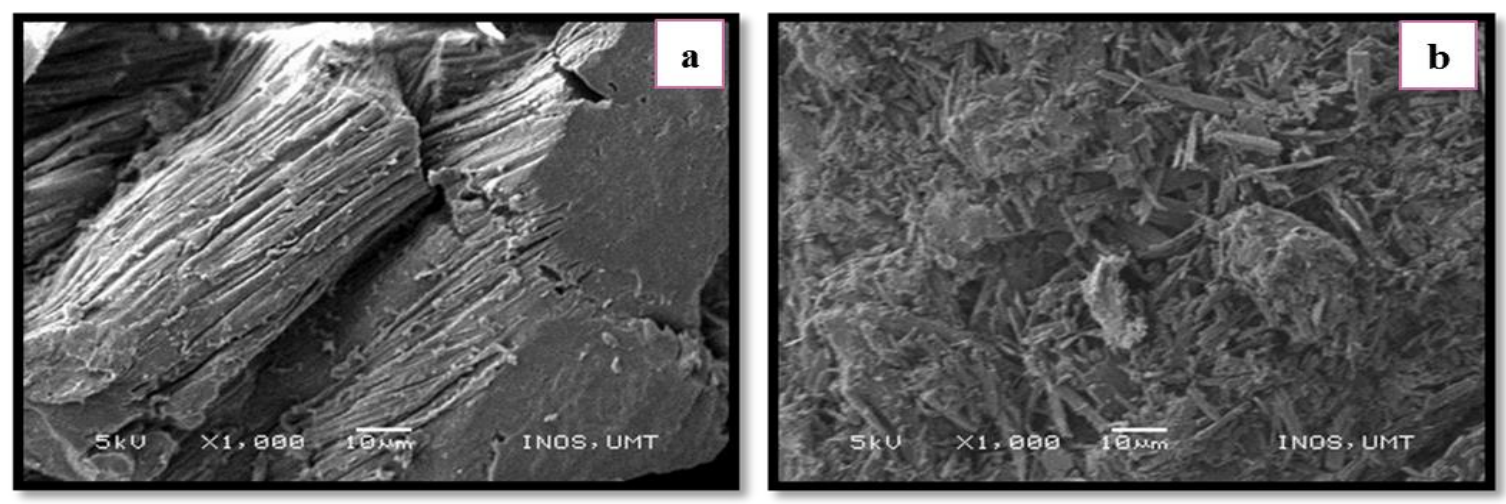

Figure 3. SEM image of the (a) $\mathrm{P}_{4} \mathrm{VP}$ and (b) $\mathrm{P}_{4} \mathrm{VP}-\mathrm{Pd}(\mathrm{II})$ complex

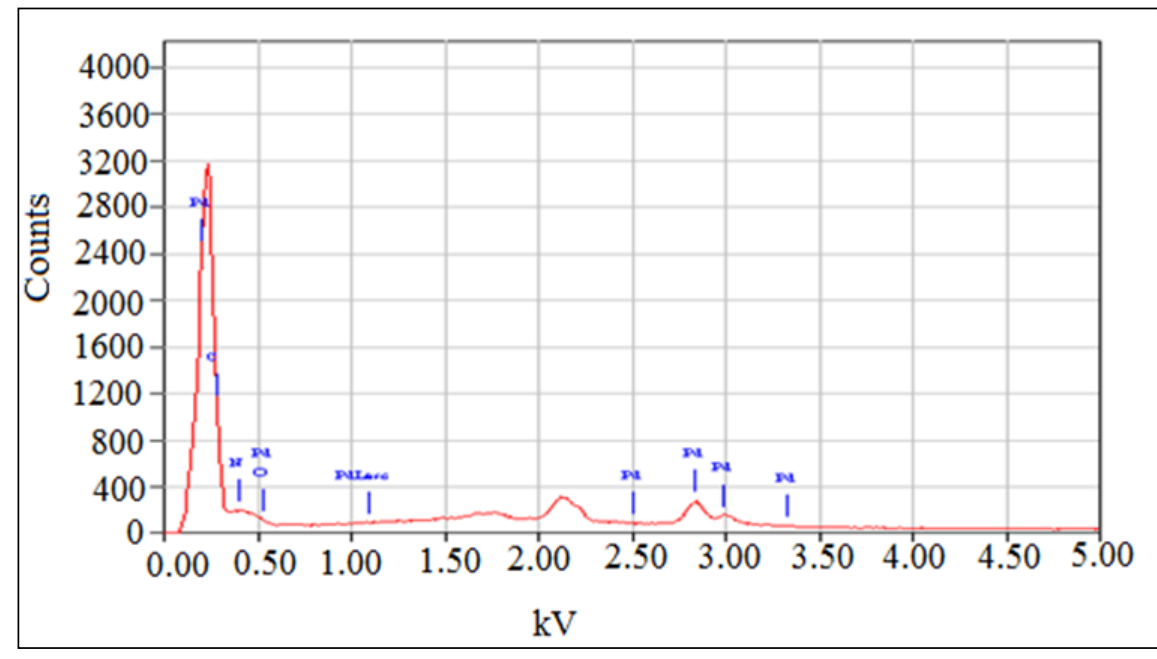

Figure 4. The EDS profile for supported $\mathrm{P}_{4} \mathrm{VP}-\mathrm{Pd}$ (II) complex 
Powdered X-ray diffraction study is regularly used to assess the quality and structural ordering of $\mathrm{P}_{4} \mathrm{VP}$ and supported catalyst (Figure 5). XRD pattern showed that the $\mathrm{P}_{4} \mathrm{VP}$ support is amorphous nature with no characteristic XRD peaks is observed. The diffractogram of $\mathrm{P}_{4} \mathrm{VP}-\mathrm{Pd}$ (II) complex showed dramatic changes compared to $\mathrm{P}_{4} \mathrm{VP}$ structure due to the represent of crystalline phase and indicated that the palladium complex which is incorporated with $\mathrm{P}_{4} \mathrm{VP}$ matrix.

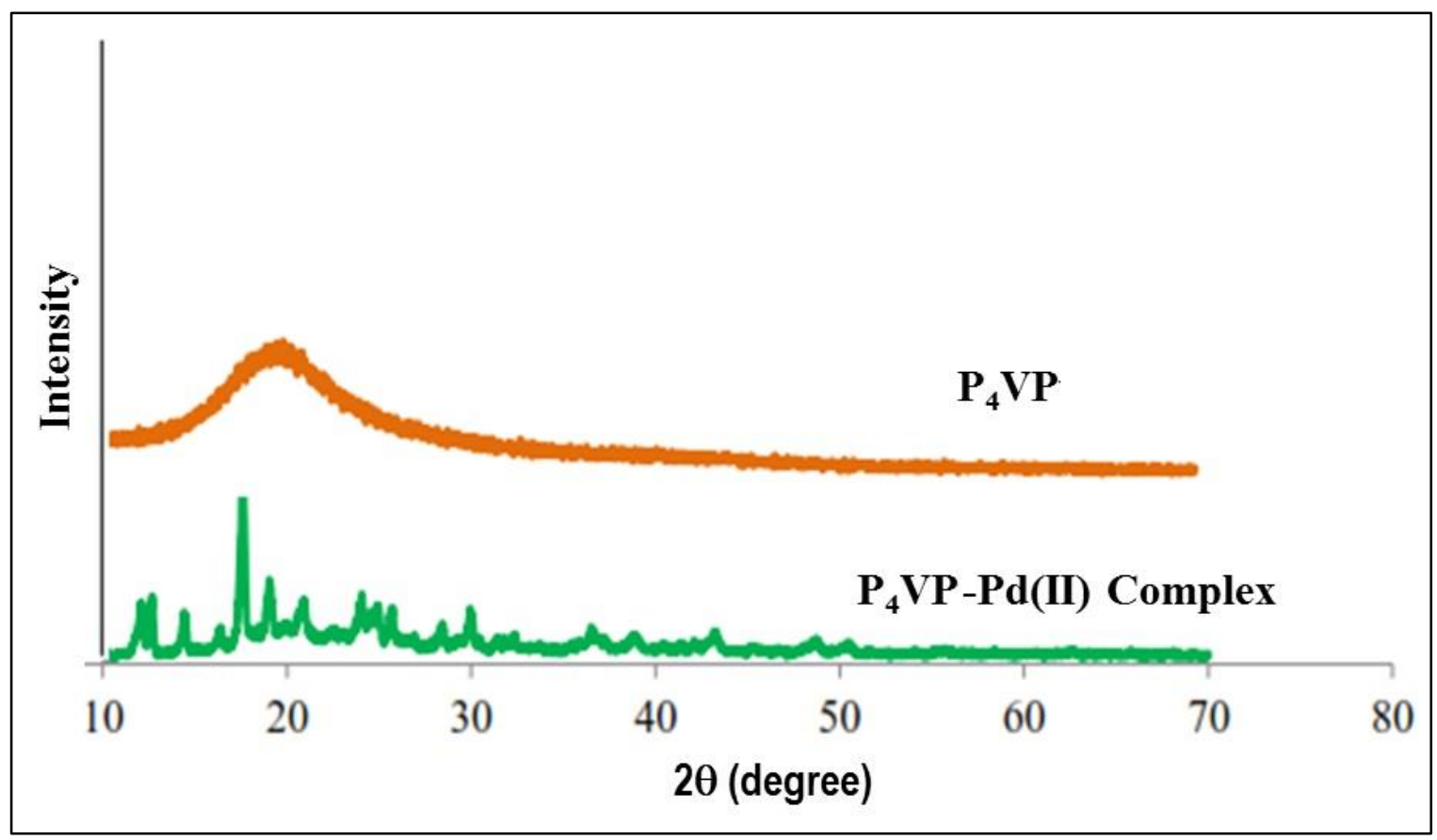

Figure 5. The XRD pattern for free $\mathrm{P}_{4} \mathrm{VP}$ and its supported $\mathrm{P}_{4} \mathrm{VP}-\mathrm{Pd}(\mathrm{II})$ catalyst

\section{Conclusion}

In conclusion, $\mathrm{Pd}(\mathrm{II})$ complex was successfully immobilized onto $\mathrm{P}_{4} \mathrm{VP}$ solid support and characterized via several of spectroscopic and analytical technique. The ease and simple preparation, stability towards air and moisture will make this immobilized catalyst as an ideal supported catalyst for $\mathrm{C}-\mathrm{C}$ bond formation.

\section{Acknowledgement}

The author would like to thank the Ministry of Higher Education and Universiti Malaysia Terengganu for the financial support through the RAGS Vote No. 57095 and Universiti Malaysia Terengganu for providing research facilities.

\section{References}

1. Kulkarni, S., Alurkar, M. and Kumar. A. (1996). Polymer supported with Schiff base functional group with cobaltous palmitate as oxidation catalyst for cyclohexane. Applied Catalysis A: General, 142(2): 243 - 254.

2. Dunnewijk, J., Bosch, H., and de Haan, A. B. (2004). Reverse flow adsorption: Integrating the recovery and recycling of homogeneous catalyst. Separation and Purification Technology, 40 (3):317 - 320.

3. Daniel, S., Rao, P. P., Nandakumar, M. and Rao, T. P. (2005). Synthesis of heterogenous phosphine-free palladium based catalyst assemblies via solid phase extraction and their characterization. Materials Chemistry and Physics, 90(1): $99-105$.

4. Augustine, R. L., Goel, P., Mahata, N., Reyes, C. and Tanielyan, S. K. (2004). Anchored homogeneous catalysts: high turnover applications. Journal of Molecular Catalysis A: Chemical, 216(2):189 - 197. 
5. Tyrrell, E., Whiteman, L. and Williams, N. (2011). The synthesis and characterization of immobilized palladium carbene complexes and their applications to heterogeneous catalysis. Journal of Organometallic Chemistry, 22: 3465 - 3472 .

6. Petruci, J., and Cardoso, A. A. (2013). A new palladium chelate compound for determination of sulfide. Microchemical Journal, 106: 368 - 372.

7. Evangelisti, C., Panziera, N., Pertici, P., Vitulli, G., Salvadori, P., Battocchio, C. and Polzonetti, G. (2009). A readily prepared, highly reusable and active polymer-supported molybdenum carbonyl Schiff base complex as epoxidation catalyst. Inorganic Chemistry Communication, 10(8): 914 - 917.

8. Emregul, K. C., Duzgun, E. and Atakol, O. (2006). The application of some polydentate Schiff base compounds containing aminic nitrogen as corrosion inhibitors for mild steel in acidic media. Corrosion Science, 48 (10): $3243-3260$.

9. Cimerman, Z., Galic, N. and Bosner, B. (1997), The Schiff bases of salicylaldehyde and aminopyridines as highly sensitive analytical reagents. Analytica Chimica Acta, 343(2): 145 - 153.

10. He, Y. and Cai, C. (2011). Polymer-supported macrocyclic Schiff base palladium complex: An efficient and reusable catalyst for Suzuki cross-coupling reaction under ambient condition. Catalysis Communication 12(7): $678-683$.

11. Zhongmin, D. and Zhibin, Y. (2015). Heterogeneous palladium catalyst constructed with cross-linked hyperbranched poly(phenylacetylene) as polymer support: A reusable highly active PPM-level catalyst for multiple cross-coupling reactions, Applied Catalysis A: General., 489: 61 - 71.

12. Selvakumar, J., Varghese, B., Raghunathan, V. S. and Nagaraja, K. S. (2007). 2,2'-[1,1'-(Propane-1,3diyl)bis(nitriloethylidyne)]diphenol, Acta Crystallographica Section E Structure Reports Online 63: 1924 1925.

13. Fonseca, J., Martinez, J., Cunha-Silva, L., Magalhaes, A. L., Duarte, M. T. and Freire, C. (2010). Insights into electronic and structural properties of novel Pd(II) Salen-type complexes. Inorganica Chimica Acta, 363(14): $4096-4107$.

14. Fan, Y., You, W., Huang, W., Liu, J. L. and Wang, Y. N. (2010). Salen-type nickel(II), palladium(II) and copper(II) complexes having chiral and racemic camphoric diamine components. Polyhedron, 29(3): 1149 1155 .

15. Soh, S. K. C. and Shamsuddin, M. (2013). Tetradentate $\mathrm{N}_{2} \mathrm{O}_{2}$ chelated palladium(II) complexes: Synthesis, characterization, and catalytic activity towards Mizoroki-Heck reaction of aryl bromides. E-Journal of Chemistry, 2013: $1-8$. 